\title{
Introduction of pragmatism in Vietnam
}

\author{
PhuHop Mai ${ }^{1,2, *}$, JunWu Yang ${ }^{1}$ \\ ${ }^{1}$ College of public management, Hunan Normal University, Changsha, China \\ ${ }^{2}$ School of Political Science, Can Tho University, VietNam
}

\section{Email address:}

mphop@ctu.edu.vn (P. H. Mai), yangwyf@aliyun.com (J. W. Yang)

\section{To cite this article:}

PhuHop Mai, JunWu Yang. Introduction of Pragmatism in Vietnam. International Journal of Philosophy. Vol. 1, No. 3, 2013 , pp. $38-46$. doi: $10.11648 /$ j.jp. 20130103.11

\begin{abstract}
Pragmatism is a philosophical school of scientific trend in non-classical philosophical movement formed in late nineteenth century, flourished in early twentieth century. It is the most unique contribution of American thought to the philosophical treasure. This movement penetrated deeply into the American ideological, political, cultural, and social life and became "semi-official philosophy of American lifestyle". During the development process, pragmatism widely circulated in many countries around the world such as England, Italy, Austria, Germany, China, and Vietnam... Pragmatism had influence in Vietnam from about 1945, when a delegation from the University of Michigan arrived in Saigon to help reform the training program at the National Institute of Administration. From that time, Pragmatism was taught in the Institute. Together with educational process, Pragmatism was also spreaded through the establishment of national politics in southern Vietnam, and through lifestyle and activities of American soldiers. Until now pragmatism has had much influence on the social life of Vietnam. However, there has not been any research related to this problem, as no studies on the introduction and development of pragmatism in Vietnam. In this paper, we introduce the processes influence and stages of development pragmatism in Vietnam. This study will have a great theoretical significance.
\end{abstract}

Keywords: Pragmatism, Educational Cultural Policy, South of Vietnam

\section{Introduction}

Pragmatism is a philosophical movement that includes those who claim that an ideology or proposition is true if it works satisfactorily, that the meaning of a proposition is to be found in the practical consequences of accepting it, and that unpractical ideas are to be rejected, is a philosophical school of scientific trend in non-classical philosophical movement formed in late nineteenth century, flourished in early twentieth century [1]. In the beginning was "The Metaphysical Club", a group of a dozen Harvard-educated men who met for informal philosophical discussions during the early $1870 \mathrm{~s}$ in Cambridge, Massachusetts. Club members included proto-positivist Chauncey Wright (18301875), future Supreme Court Justice Oliver Wendell Holmes (1841-1935), and two then-fledgling philosophers who went on to become the first self-conscious pragmatists: Charles Sanders Peirce (1839-1914), a logician, mathematician, and scientist; and William James (18421910), a psychologist and moralist armed with a medical degree It is the most unique contribution of American thought to the philosophical treasure [2]. This movement penetrated deeply into the American ideological, political, cultural, and social life and became "semi-official philosophy of American lifestyle".

Pragmatism was born under the influence of living conditions and the nature of American social life; it appeared when the philosophy fell into a worldview crisis and especially crisis of cognitive methods. Along with Positivism, Structuralism, and Scientism... in the tendency of science or modern rationalism, Pragmatism guided "about the reconstruction of the entire philosophy"; their key was to implement their "third way" in philosophy, with the desire to go beyond the materialism and idealism, and to dismiss the fundamental issues of philosophy which had been set in a number of centuries.

Pragmatism publicly declared to overcome and transformed metaphysical mode of thinking of modern philosophy, which meant to bring the abstract philosophical concepts onto practical land and to seek for meaning of philosophical issues in its relation to the human life. The Pragmatists protest to take the separation between subject object, nature - phenomenon, mind - characters... as the starting point of traditional philosophy such as the issue of 
foundation and essence. It suggested bandonning the philosophical systems which considered themselves as popular and absolute. They thought that the main task of the philosophy was to identify the epistemology and methodology of science, putting the research objects of philosophy and science within the current lifetimes. During the development process, pragmatism widely circulated in many countries around the world such as England, Italy, Austria, Germany, China, and Vietnam...

Pragmatism had influence in Vietnam from about 1945, when a delegation from the University of Michigan arrived in Saigon to help reform the training program at the National Institute of Administration. From that time, Pragmatism was taught in the Institute. Together with educational process, Pragmatism was also spreaded through the establishment of national politics in southern Vietnam, and through lifestyle and activities of American soldiers. However, when Vietnam was unified in 1975, due to the elimination of American cultural lifestyle, Pragmatism no longer had conditions to develop. In 1986, with the reform and opening policy, Vietnam created the conditions for acquiring the external factors, and since 1990s with the establishment of new program for philosophy, Pragmatism has been taught in the universities and colleges; some ideologies of Charles Sanders Pierce, William James and John Dewey... are introduced, and many graduate theses exploit this doctrine.

To understand the history of Pragmatism in Vietnam, we need to understand two major periods: the period before 1975: the period associated with U.S. policies in South Vietnam, and the period from 1986 to the present: the period of reform, opening, integration, and development. In this period, Pragmatism infiltrated into many aspects of social life; it also affected the economic - political thinking. In addition to positive impacts, it also caused adverse effects on many aspects of society, such as: individualism, selfish, pragmatic, and self-seeking lifestyle, corruption, bribery, bureaucracy, indifference to the difficulties of other people, business, dishonest lifestyle... which gradually grew. The Communist Party of Vietnam recognized and considered those dark sides as "a big risk and challenge, related to the survival of the Party and the regime" [3]. However, until now research works on Pragmatism only aim at introducing the basic ideologies of some representative philosophers. There has been no research work the history and the development of this doctrine in Vietnam. Therefore, this article is a great theoretical significance.

\section{1945 to 1975 American Empire's Cultural and Political Policy in the South of Vietnam}

Pragmatism was formed in in 1870; it influenced many countries in the world. However, it influenced Vietnam later than other countries, and the South of Vietnam is the first place to be influence in Vietnam. This process associated with the war against American Empire.

The South of Vietnam was formed from the 17th century, this used to be a wild land area of lowland systems, swamp, and rivers. This land was developed by the farmers from various locations in the Central and North of Vietnam and Chinese. After nearly a century, the South of Vietnam was considered a cultural region [4]. A century was not long time to form a regional culture, and when the new peoples arrived at the new land, they brought along with them their own cultures which had been formed thousands of years ago. Those cultures mixed together and created the foundation of cultural value system of the South of Vietnam. These values has undergone the interaction with the natural and social environment in the history, gradually created the cultural values of the South today. The South of Vietnam had long historical and cultural process and young strength which has been built up by the peoples here. From the geographical position, the South became the center of the acculturation, which gave the region unique characteristics and a new face compared to the other cultural areas in Vietnam. The system of cultural values in the South included the traditional culture of the nation and the core ethnic values which formed the specific cultural style of the region. The opening characteristic of a new land created the "dynamic, responsive, dare to think, dare to do" characteristics of the people. Opening characteristic is the basis for the admission and acculturation of a number of cultural values.

From the latter half of the nineteenth century, the trend of annexation and colonial expansion of the imperialist countries became strong worldwide. Countries in Asia and Africa... gradually became the colony of British, France, Netherlands, Russia, and Germany... Vietnam used to be a colony of French colonialists in the mid-nineteenth century. After squelching the patriotic movements, and completing the basic pacification in Vietnam by military, the French colonists conducted the colony exploitation and imposed a large-scale policy of domination on the fields of: economy, politics, cultures, and education... in order to make Vietnam become a reclamation colony, ensuring the super-profits for France. "French colonialists forced the stupid people policy to mentally enslave the masses; made the masses turned to the crowd of inferiority and cowardice in front of the power of French civilization; made them loose the confidence in the ability of the people and future of the nation; cut off all good traditions to faithfully serve the interests of imperialism. French colonists implement the educational policy for the only purpose of training interpreters and servants in the colonial administrative agencies, and gradually spreaded French and Vietnamese alphabet, limited the influence of Chinese characters"[5].

At the beginning of the XX century, the French Colonists not only created a new education, but also eliminated the role of the old education. A system of France-Vietnam Schools was expanded to replace the Chinese character education. Examination courses such as Huong, Hoi, and 
Dinh were cancelled in order to terminate the role of feudal elites. By 1917, the society of Vietnam was "Frenchified". The The French Colonists eliminated the good tranditions of Vietnamese people, and replaced by dissemination program of "French civilization" to create a generation of Vietnamese who loosed their "origin", without patriotism and sense of people who loosed their own country, and became slaves to serve the French dominance.

From 1949, the Civil war of China ended, the North Korea war broke out, and the American politicians were scared about the communism wave in the third world countries. The U.S. government launched the Domino Theory, according to which the United States believes that if a nation followed the Communism, the pro-Western countries nearby would be threatened. Therefore, the United States began to aid the French colonists in the war against Viet Minh (Democratic Republic of Vietnam), an organization that had the relation with the Soviet Union and China. At the same time, the U.S. actively prepared for the establishment of "Mekong block" including Cambodia, Laos, and Thailand, in order to turn the three countries along the Mekong River into the military bases, and to use these three countries as the door into Indochina. During this period, the revolutionary movement in Vietnam flourish, the struggle against the French broke out continuously; in 1954 the French colonists were defeated in Dien Bien Phu and forced to sign Gienerv ${ }^{1}$ Agreement to recognize the independence of Vietnam. According to the agreement, Vietnam was temporarily divided into two zones, the $17^{\circ}$ parallel was considered the border, and in 1955 French troops withdrew from the South of Vietnam; however, there were many provisions in the Agreement relating to their responsibilities which had not been implemented, including provision on the organization of Trade union general election between the North - South of Vietnam. Taking advantage of that opportunity with the "sponsor" guise, but in fact the American Empire considered the South of

\footnotetext{
${ }^{1}$ The Geneva Conference (April 26 - July 20, 1954 was a conference which took place in Geneva, Switzerland, whose purpose was to attempt to find a way to unify Vietnam and discuss the possibility of restoring peace in Indochina. The Soviet Union, the United States, France, the United Kingdom, and the People's Republic of China were participants throughout the whole conference while different countries concerned with the two questions were also represented during the discussion of their respective questions, which included the countries that sent troops through the United Nations to the Korean War and the various countries that ended the First Indochina War between France and the Việt Minh. The part of the conference on the Korean question ended without adopting any declarations or proposals. On Indochina, the conference produced a set of documents known as the Geneva Accords. These agreements separated Vietnam into two zones, a northern zone to be governed by the Viet Minh, and a southern zone to be governed by the State of Vietnam, then headed by former emperor Bảo Đại. A "Conference Final Declaration", issued by the British chairman of the conference, provided that a "general election" be held by July 1956 to create a unified Vietnamese state. Although presented as a consensus view, this document was not accepted by the delegates of either South Vietnam or the United States. In addition, three separate ceasefire accords, covering Cambodia, Laos, and Vietnam, were signed at the conference.
}

Vietnam the important area in the strategy against the communism in Southeast Asia and began the intervention activities.

After the agreement, the North of Vietnam gradually built the country according to the socialist model of the Soviet Union and China, led by the Communist Party, and considered the Marxism-Leninism as the main ideology. Therefore, philosophy teaching mainly focused on the Marxist and Leninist philosophy. Besides, the North of Vietnam also applied the methods of Mao Zedong in the "mass motivation" and building the society. "In general the studying and teaching of Philosophy in the North of Viet Nam aimed at swerving the political road of the Communist Party of Vietnam, and to describe the state policies"[6]. It could be said that the philosophy teaching at universities and colleges in the 1960s valued the politics, which limited the high generality and scientific abstraction of philosophy and made the philosophy teaching loose the important role that was to equip the learners with worldviews and methodology. However, since 1970 the "politicization" issue in philosophy teaching was gradually improved. After the country was unified, the teaching, exchanging, and exposure of philosophical knowledge between the North and the South of Vietnam has contributed to enhance the knowledge and capacity of philosophical thinking to a higher level with a more objective and scientific view to philosophy besides the Marxist philosophy. In short, the philosophy spreading in the North before 1975 mainly emphasized on the MarxistLeninist philosophy and the philosophy of ancient China, other philosophical ideologies did not have conditions to develop.

The society of the South from 1954 to 1975 showed political chaos. When the North of Vietnam built the socialism, the people in the South of Vietnam lived in wars, under the under the rule of the Saigon government and the new American colonialism. There was fierce battling between the new American colonialism and the old French colonism. The Social and political situation was always unstable; the tense atmosphere was covering. My-Diem ${ }^{2}$ used bribe and violence to eliminate the opposing forces. The internal contradictions of the Saigon government gradually developed. The armed struggling movements and

\footnotetext{
2 Jean Baptiste Ngo Dinh Diem (About this sound listen; 3 January 1901 2 November 1963) was the first president of South Vietnam (1955-1963). In the wake of the French withdrawal from Indochina as a result of the 1954 Geneva Accords, Diem led the effort to create the Republic of Vietnam. Accruing considerable US support due to his staunch anticommunism, he achieved victory in a fraudulent 1955 plebiscite. A Roman Catholic, Diem pursued biased and religiously oppressive policies against the Republic's Montagnard natives and its Buddhist majority that were met with protests, epitomized in Malcolm Browne's Pulitzer Prize winning photograph of the self-immolation of Buddhist monk Thich Quang Duc in 1963.[3] Amid religious protests that garnered worldwide attention, Diem lost the backing of his US patrons and was assassinated, along with his brother, Ngo Dinh Nhu by Nguyen Van Nhung, the aide of ARVN General Duong Van Minh on 2 November 1963, during a coup d'état that deposed his government.
} 
political struggling movements broke out continuously which made the Ngo Dinh Diem regime flood in deep crisis, the Saigon government fell into awkward and passive situation...The commanders standed out to lead the campaign against Ngo Dinh Diem and made plan to overthrow the Diem, Nhu government. The U.S. Empire supported Duong Van Minh to overthrow the Diem, Nhu government, killed Ngo Dinh Diem and Nhu (January/1963). Then other successive coups occurred. The political instability leads to instability in many aspects of life, the wars were fiercer and fiercer. In order to divide Vietnam for long time, and to implement the new colonialism, American Empire massively sent U.S. troops and aid to the Republic of Vietnam as well as direct joined in the combat, planning and control war strategies (Special war, particular war, and Vietnamization of the war...), at a total cost of over 686 billion U.S dollars (the price in 2008)[7]. American Empire also sent thousands of specialists in field of military and education to Vietnam. The Republic of Vietnam also sent soldiers to the U.S for training. In the society, the atmosphere of oppression and terrorism covered, the general mood of the people was stress, anxiety, always fell insecure. Many struggles for freedom, democracy, welfare, civil rights, struggles for national culture, and struggles against the invasion of foreign culture, and struggles for withdrawal of U.S. troops from the South of Vietnam... broke out continuously.

Along with the massive American troop landing in the South, the ideas of Western culture, American culture, Western - America lifestyles were introduced quickly, which significantly affected the lives, thoughts, and culture in Southern urban areas in 1954 - 1975. The society in the Southern urban areas in 1954 - 1975 was mixed by a number of cultures including both Eastern and Western cultures, but the Western cultures and American cultures were the most obvious ones. Many schools of philosophy, aesthetics, literary critic were spreaded into the South to coexist and created a very diverse culture and the cultural life was extremely vibrant.

The translation and publishing movements also developed strongly: In Sai Gon, there were hundreds of publishing houses. Besides the book publishing, newspaper also "developed" well. In 1959 there were "15 weekly newspapers, 31 monthly magazines and semi-monthly magazines, 32 special magazines publishing weekly and monthly, and the total of Vietnamese magazines was 78"[8]. In field of translation, from 1954 to 1975 the quantity was as follows: 57 works in German, 58 works in Italian, 71 works in Japanese, 97 works in English, 499 works in French, 358 works in Taiwan-Hongkong languages, 120 works in Russian, 273 works in American English [9].

In field of philosophy: From 1945 to the mid - 1950s, due to the power transfer - social conflicts, and fierce war... together with the influence of France.... Almost all the the intelligentsias only pay special attention to Existentialism. Besides, they also pay attention to Epistemology, Heidegger philosophy (through translations and French books). However, the scholars in the South could not have intensive knowledge about Epistemology as well as the ideology of this German philosopher. Thus, Tran Van Doan had the comment "The "ghost" of Nietzsche, Heidegger, Franz Kafka, as well as the "the trend to make a synthesis" of Oriental ideology (for example Rabin Tagore and Daetzu Suzuki), the western philosophy turned the scholars in Sai Gon into the psychoanalysts and halfway phenomenon. Thus, they transformed Epistemology into a fashionable "trend", just like Paris fashion" [10]. Besides, Marxism was studied by one scholar. However, those works often discussed about Karl Marx as an intellectual rather than a rouge. Some works mentioned about revolutionary aspect of Karl Marx but explaned wrongly in order to make the readers tear away rather than get close to the his revolutionary ideals. By using the vague philosophical theories, in the name of Marxism they requested to reconsider Marxism in order to deny the living and revolutionary soul of Marxism. To reconsider Marxism, they tried to value Marx, especially the young period of Marx then tried to fight against the successors of Marxism. The stated that Marx in the young period is true Marx, true Humanist. When Marx got older, he went far away from Humanism. They also stated that Marx was revolutionary, but the successors of his carrier went far away from his revolutionary ideologies. The reconsidering scholar took away the nature and dogmas of Marxism-Leninism. The strongest doctrine against the Marxism was Spiritualism Personalism ${ }^{3}$; this doctrine had the slogan "Eliminate communism", it also mentioned about the use of political tools to suppress all patriotic tendencies and the tendencies against it. Spiritualism - Personalism used to be the main official ideological foundation for the political regime, a "nation" in the South of Vietnam. It is established by Ngo Dinh Diem and his brother on the basis of American supports, so that it protected the interests of the American Empire, It fighted against other colonialism which competed the interests with the American Empire, itself, and protected the new government regime.

By the end of 1950s, with the supports of the American Empire-Diem and when Vietnam sent officials and students to the United States, Australia, New Zealand and other countries to study, the French influence gradually faded. And from here, the influence of the United States began to rise. Pragmatism encountered a favorable land to flourish and grow. But pragmatism came to the South of Vietnam in a different way compared with other places. For example, in China, Pragmatism was introduced by its founder - John Dewey and his student Hi Thich with a pure academic spirit.

\footnotetext{
${ }^{3}$ Spiritualism - Personalism was a philosophical-political doctrine of Ngo Dinh Nhu (1911 - 1963) based on the Personalism (Le Personalize) of French philosopher Emmanuel Mounier. However, the philosophical foundation originated from the selection of humanism values of Confucianism. This doctrine was established to make the ideology somewhere between the collective perspective of the communist doctrine and individualism of capitalist doctrine. This theory is the ideology for Can Lao- Personalism Party.
} 
Whereas in Vietnam, Pragmatism was introduced to serve the political purposes, thus Pragmatism in Vietnam was not propagated fully and openly, it had political color rather than pure pragmatic, serving the purpose of U.S. imperialists. Due to this reason, in Vietnam pragmatism was considered "bad, not worth, and despised". However, we could not totally deny its historical role in Vietnam.

It could be said that the mark for the appearance and influence of pragmatism in Vietnam was 1945, when a team of Michigan University arrived in Sai Gon to reform the staff training program at National Administration Academy. From that time, the influence of American "pragmatism" education started to develop to become the third tradition after "Confucianism" and "classical French"4 Although the new government and American empire made much attempt to reform the Vietnamese education until 1964-1965, it was still affected deeply by the French education. However, the "liberal" philosophical direction showed a new wind in the education. Until the early year of 1970s, the innovation process started to speed up. The Vietnamese education followed the American education philosophy, building the education on the foundation of Jonh Dewey's educational philosophy written by Lavergne and Sassani [11] for The National Administration Academy. From this time, the Vietnamese scholars knew about pragmatism, and pragmatism was taught in the university curriculum officially. Besides, the students studying abroad in the U.S also contributed to the introduction of this doctrine into Vietnam.

In 1972, on the basis of Vietnamese culture and actual social demands. The Educational Cultural Council compiled the "Educational Cultural Policy". This policy was built on the American educational spirit, and particularly from educational philosophy of J. Dewey[12]. That was the liberal, human, active, with quality and memorable achievements.

The education is human because all people have the right to receive education for free until the end of High school and to receive support in university and higher education level.

The education is positive because it always updates new educational methods from developed countries. The teaching tools and means are equipped fully. The lecturers and educational managers are always updated with new and advanced knowledge. These points make the education have high quality.

Basic contents of that policy are expressed in the main points as follows:

\footnotetext{
${ }^{4}$ From the $10^{\text {th }}$ Century to the early $20^{\text {th }}$ century, Vietnam was influenced by the Confucianism education. The first "National education workshop" held in 1958. The workshop brought about a new view related to philosophy by proposing 2 principles for education. Three philosophical principles: "Humanism, nation, and liberal." Identify the transition from Confucianism to French education. The second workshop was held in 1964 discussed about l'école unique of France, focusing on the personal differences among the students. Its second topic was to confirm the three philosophical principles: "Humanism, nation, and liberal", which was discussed and accepted in the workshop 6 years ago.
}

* All citizens have right and obligation to study in order to develop capability, to complete the dignity, and to serve the nation and mankind.

* All citizens have the freedom to choose the major, curriculum and school which are suitable for them or for their children depending on the capability and orientation.

* The nation must facilitate all citizens equally to follow the learning depending on the capability. The nation must encourage and support all people who have capability but lack learning means.

* The nation must spend part of the state budget for education development.

* The university education must have autonomy to ensure that the training, research, and creation could be carried out and developed with convenience. "Education is life itself". Because Education is life itself, the universities could not separate it from the actual activities, and knowledge could not be forced from outside. Thus, we do not have the common education for all people. The teacher must be aware of and respect the differences among the students. Education must be the process of the students, not the process of the trainers. Education is the process in which the learners are the center. In other words, education must be a profoundly democratic process.

* Respect the scientific spirit, build the democratic education binding theories and actual life. Build the education in which theories go with practice[13].

However, due to the increase of war, the education carrier including University education encounters many difficulties, especially in sending students to study abroad. Ministry of Education and School of Universities must invite foreign professors to teach the students; however the demand was not satisfied. Therefore, in 1965, a professor worked with the agencies for foreign cultural collaboration to release the slogan "We want to bring the brain in" in order to đẩy strengthen further supports. In 1971, together with the establishment of private universities and community universities of American Style, The VietnamAmerican Association collaborated with Education Council under Ministry of Education to implement the program of translating American books for the professors and students in Vietnam and the dissemination program of general knowledge about literature, science and art which was being implemented by Vietnam - American Association[14]. In the spirit of liberal education, and with the help of the U.S., although the national education only developed for 20 years (from 1955 to 1975), and was heavily influenced by the war and political instability, the state budget was limited and largely spent for national defense and internal affairs (over $40 \%$ of the state budget for national defense, and about $13 \%$ for internal affairs, only $7-7.5 \%$ of the state budget was spent for education)[15]. The education of the Republic of Vietnam developed significantly, met the rapidly increasing demand of the people, trained a lot of educated and capable graduates to contribute to nation building, and created a solid career.

Besides education, Pragmatism also influenced through 
political - thought struggles of U.S: At the building No. 8, Le Quy Don Street in Saigon there was a sign: United States Information Service - USIS. It was the name of the United States information service organization for the organization in Saigon, a branch of the United States Information Service, under the direction of the U.S. Embassy in Saigon. USIS not only had media functions, it was also the focal point of psychological war and ideology destruction activities of overseas CIA. Do not have an activity of cultural communication apparatus which is not derived from the foreign policy of the U.S. State and CIA intrigue of the so-called expansion of American power, American lifestyle, and ideology across the U.S. world. USIS is delivered direct program activities of dozens of cultural institutions in the United States Information Saigon and the provinces of South Vietnam.

All cultural and promotional activities of that mechanism oriented from the foreign affair policies of the U.S Government and intention of CIA which was called American power, lifestyle, and ideology in all over the world. USIS was appointed to direct the operation program of dozens of U.S cultural and information centers in Sai Gon, provinces, and cities in the South of Vietnam. Directors of USIS were personnel of CIA. In the fierce period of the war from 1966 to 1970 USIS was renamed to be JUSPAO - Joint United States Public Affairs Office. Besides a free source of English-language books was Asia Foundation (Agency for Asian-European Cultural Aid), a non-commercial organization, which gave books to military personnel and civil servants for free. With the goal of building the "First Republic", U.S propagandized freedom and democracy issues; they praised the American democracy, American way of life, in which John Dewey's ideology was one of the ideologies to be introduced popularly...

In addition to education, political pragmatism affected Vietnam through economic supports and from the lifestyle of American soldiers. When the American imperialists occupied, they established the generally pragmatic lifestyle in Southern urban areas and among the labors as a tool for enslavement. Unlike in the U.S., the South of Vietnam was "a society almost without any significant production, but consumed living facilities from the capitalist countries, even the far more than capitalist countries"[16]. By spreading that lifestyle, the American imperialists gave the Southern people a living habit, so that they could not live without the comforts, and forever depended on the U.S. Empire. Lifestyle of the "consumer society" was not only confined to physical life, but also into the spiritual life. In addition to the publication of books, there were modern multi-media and movies... which attracted the people to rush for the "fashion" for any price to avoid being considered "rustic".

However, the efforts of US Empire-Nguy of establishing an American society only existed in about 20 years. In 1975, all influence of the US in Vietnam ended, Vietnam achieved the independence and unity; the country started to establish the socialism. During that time, we could see the influences of American cultural in general and philosophy in particular.

\section{1975 - 1995 Establishment of Socialism and Criticize American Culture}

From 1975 to 1994 , the U.S. embargoed against Vietnam, and used its power to prevent efforts which aimed to help Vietnam from international countries. During this period, from 1977 to 1978 Vietnam and the United States negotiated normalize the relations between the two countries but failed, partly because Vietnam required the United States to compensate for losses and damages which the U.S caused in Vietnam, but the United States rejected. In 1993, the United States announced that it no longer prevented other countries from lending to Vietnam for loan repayment to the international financial institutions. In 1994, President Bill Clinton announced that the U.S completely removed the embargo against Vietnam and established a liaison agency between the two countries. On July $11^{\text {th }}$, 1995, President Bill Clinton announced to normalize the diplomatic relations with Vietnam.

Right after 30-4-1975, a wave of national pride and American culture elimination was spreaded throughout Saigon. Vietnam depended on the U.S in many years in fields of military, fashion, music, and food which caused large impact on the national psychology. However, those things quickly disappeared.

For the U.S., the embargo against Vietnam was tightened. Washington cut all diplomatic relations with Hanoi. During the years after the war, the embargo was strictly enforced: There was no form of diplomatic relations between the two countries, except for some selective activities for humanitarian purposes such as sending medicines for disease treatment, or research books - which were still limited. For example, some Vietnamese people living in the U.S. wanted to send 1-2 books to scientific institutions in Vietnam and faced a lot of difficulties: Due to the embargo, U.S. posts returned or destroyed all the reference books sent to Vietnam. In the book "Traveling to Vietnam" (1998), Mary Hershberger gave the comment when writing about the movement of the American peace activists: "The U.S. government embargoed against Vietnam on each activity and frozen all international relations of Vietnam, and it even meant the U.S cooperated with the Khmer Rouge in Cambodia"[17].

The political situation had hostility color: President Ford vetoed Vietnam's membership in the United Nations; frozen 150 million dollar assets of Vietnam in the U.S, prevented Vietnam from joining into the World Bank and The International Monetary Fund. The U.S Congress even applied stronger embargo to prohibit any form of aid or support for Vietnam; and tightened legal procedures for immigration.

Not only Americans, Vietnamese people of the old 
regime after evacuating to the U.S. in 1975 also held hostility against Vietnam. A very large number of them were "implacable" with communists; even some extremists assaulted and murdered anyone who intended to return to Vietnam to do business, or to support Vietnamese government [18].

For Vietnam, after the victory spirit of national pride was increased. The North's strategy is to destroy and clear the entire Southern literature because it represents a "reactionary" culture compared with the socialist culture. So right after taking over the South of Vietnam, may magazines in the North such as Literary Magazine and Entertainment magazine etc...published more than 200 articles about this policy. After liberation, the campaign "hunting remnants of American culture" became more and more drastic. Le Duan in the 5th National Assembly released the Directive: "After the liberation, our people have done a lot of work to wipe out the traces and remnants of such culture. This work should be continued in a persistent, positive and thorough way."On 26/06/1976, The Central Executive Committee of Communist Party released further directive: The establishment of new culture is carried out along with the struggle to wipe out the remnants of the U.S. culture in the South. It is the culture of subjugation, which is hybrid, depraved, extremely reactionary"[19]. The Directive was implemented through the activity of burning books and passing though the strategy "Proscribe depraved-reactionary culture". The strategy had 2 purposes: (1) In term of politics, proscribe the reactionary ideology against the regime and (2) in term of culture, eliminate the forms of "depraved culture of capitalism"- specifically the American culture.

One of the critical works for the new government when the Southern regime collapsed was to seal and confiscate books in the libraries. The works of major publishers and bookstores in Saigon such as the Khai Tri, Song Moi, Doc Lap, Dong Nai, Nam Cuong, and Tri Dang... were sealed and banned.

There were many writers in the South of Vietnam who specialized in different fields. In terms of Western philosophy: Le Ton Nghiem, Tran Van Toan, Tran Thai Dinh, Nguyen Van Trung, and Tran Bich Lan ... Eastern Philosophy: Nguyen Dang Thuc, Nghiem Xuan Hong, Nguyen Duy Can, Nguyen Khac Kham, Nghiem Toan, Kim Dinh, and Nhat Hanh... In term of editing: Nguyen Hien Le, Gian Chi, Le Ngoc Tru, Le Van Ly, Truong Van Chinh, Dao Van Tap, Pham The Ngu, Vuong Hong Sen, Thanh Lang, Nguyen Ngu I, Nguyen Van Xuan, Le Tuyen, Doan Them, Hoang Van Chi, Nguyen Bat Tuy, Phan Khoang, Pham Van Son, Nguyen The Anh, Nguyen Khac Ngu, and Nguyen Van Sam ...

Entire books published in the South of some authors mentioned above were "equated" as the remnants of the American-Nguy regime, enslaving, reactionary and depraved culture. Authorities at the level of wards, districts, and cities released the directives to collect all sorts of books, novels, reference books, and textbooks to burn out. There was no official statistics, but many researchers estimated that hundreds thousand of books and tapes and CDs were burned in Saigon during that strategy. The youths not only confiscated books and cultural materials in the printing houses and stores, but also on the book shelves in private homes.

In terms of education, to rebuild the new education system, the Communist Party of Vietnam recognized that "Teachers and students in universities and professional college in the South are the Vietnamese people; they are the victims of enslaving and reactionary education. We shall facilitate them with complete education, so that they will quickly become patriotic and socialist intellectuals. We must strengthen the political and thought education in schools and make it the top mission of education sector"[20].

In 1975-1976, in addition to teaching cultural and professional subjects of new programs and contents, the program must include coursework in political and social activities throughout the school year and for all students from the first year to the ending year.

The contents concentrated on three majors:

- Great victory of the war against the American imperialists to protect the country.

- The revolutionary way and policy of Vietnam; The way of revolutionary education.

- Obligations and rights of the new citizens and revolutionary cadres.

In which, the immediate task was to organize the reeducation for all teachers and students who worked and studied under the old regime. The major contents were Marxism-Leninism and elimination against American imperialists - Nguy.

To accomplish important tasks of the Party in the field of ideology, the Ministry of University (now the Ministry of Education and Training) sent Marxism - Leninism teachers, including philosophy teaching staffs to the South to teach Marxism-Leninism (including philosophy) for almost all universities; the teaching subjects were all lecturers and students who were working and studying under the old regime, in order to make the consistency of ideology system in the country. The Marxism-Leninism staffs and leturers in general and philosophical lecturers in particular performed this task. And it could be seen that in nearly 15 years after the liberation, the philosophy teaching strongly focused on Marxist-Leninist philosophy, other philosophies were not concerned properly, especially American philosophy (except for Chinese philosophy).

\section{The Turning-Point of Innovation Process for Teaching Philosophy}

In the early 1990 s of the 20 th century, recognized the importance of teaching the science subjects of MarxismLeninism and philosophy in the new period, Communist Party of Vietnam was established a council to recompile the 
new curriculum for science subjects Marxist-Leninist and philosophy on both content and form. The new development of philosophy education in Vietnam is the introduction of the history of philosophy beyond Marxist (before Marxist and modern Western) into the curriculum. The curriculum was kept partly for pragmatism, and reference books also introduce the thought of some pragmatists as Chales Peirce, William James, and John Dewey. Many graduated thesis and post university also study Pragmatism. Previously, pragmatism and modern Western philosophical movements barely been introduced or have been introduced aiming to critical. At this time, the philosophy study of Western capitalist not only to condemn and criticize but also to find out the strong point, positive side and the true value of this philosophy. With the motto of research on the spirit of innovation is respected all different cultures including philosophy.

In order to implement this task, Communist Party of Vietnam considers: "Innovative teaching staff, teaching and learning methods, rewritten textbooks" is the main task. The Prime Minister has signed a decision to establish the Central Council compiled under the direction of the national curriculum the science subjects of MarxistLeninist, Ho Chi Minh Ideology and funding for the KX.10 program to compile 5 curriculum unit, in which including Marxist-Leninist Philosophy (published in 1999). The curriculum has been tried many innovations in the direction of increasing the historical pre-Marxist philosophy and modern philosophy which is the basis for the right awareness on Marxist-Leninist Philosophy inherited and developed.

However in 2008, Ministry of Education and Training issued a new curriculum for the political theory courses at universities and colleges. According to the Decision on issuing 52/2008/QD-GDDT on promulgating the program of political theory courses for colleges and universities to teach students who were not specialized in MarxismLeninism and Ho Chi Minh ideology. The political theory program included 3 subjects: The basic principles of Marxism-Leninism, Ho Chi Minh ideology; and Revolutionary policy of the Communist Party of Vietnam. This program rejected the history of philosophy. Hence the writer and educator- Nguyen Ngoc gave the comments in "Nghi Doc Duong"- Think along the way that "... I think Marxist-Leninist philosophy is necessary, the subjects mentioned above (3 subjects) may also be necessary. But why, at least at the university level, the general philosophy and history of philosophy, including both Eastern and Western philosophy are not taught and introduced. Marxist - Leninist Philosophy may be the peak of philosophy, but it certainly is not the only philosophy of humanity, nor the last philosophy in the history. If the students do not know philosophical history of humanity basically, their knowledge of Marxist-Leninist philosophy will also be poor and superficial..."[21].

Vietnam has a long traditional history, rich and diversified cultures, with deep thought, strong bravery in front of the challenges. But Vietnam still lacks the independence of philosophical thinking, and lacks famous philosophers. There are periods, time, and places where philosophy is not understood properly, the philosophy is not treated with fairness and lack of esteem. And the philosophy program in the universities nowadays (especially in the book "The basic principles of MarxismLeninism") is containing many shortcomings; the philosophy is still not understood well and comprehensively. In some universities and training institutions, there are philosophy department, only philosophical students are studying philosophy in a fairly complete way. However, most students and high education students of other fields only know a very small portion of a particular philosophy, which is Marxist-Leninist philosophy. And there is sad story when even Marxist-Leninist philosophy is now "integrated" with political economics, and scientific socialism to become a subject with abstract name and difficult to understand "Basic principles of MarxismLeninism". This program only focuses on a particular philosophy, and does not introduce about the development of philosophical thought of humanity. There are few research papers with high scientific value or great works of philosophy in Vietnam. At the same time, many famous philosophers of different philosophical schools do not have the appropriate voice and position in the minds of students and graduate students. Besides, many achievements of philosophical mainstreams and schools such as existentialism, positivism, and pragmatism ... have not been widely introduced.

As mentioned above, Vietnam is now paying too much attention on a particular philosophy - Marxism - Leninism philosophy. Therefore, the introduction of other philosophical ideologies of humanity will create powerful incentives to promote thinking and philosophy of science in Vietnam, contributing to help the Vietnamese philosophy keep up with the development of humanity. Thus, Vietnam can actually bring about the new life for philosophy, enhance the effectiveness of philosophy teaching and training in the present context - the context of the globalization and internationalization, which taking place powerfully.

\section{Conclusion}

Pragmatism has affected Vietnam and it has left unique marks; it is now affecting many aspects of the social life. This Philosophical school was introduced into Vietnam in a different way compared to other places, such as in China or Japan. In the South of Vietnam, pragmatism was introduced in conjunction with political purposes and lifestyles of American soldiers. It was this reason why Pragmatism was always despised and misunderstood. Therefore, the comprehensive research and introduction of this doctrine in a scientific way has significant meaning, thereby to help Vietnamese people see the development of human knowledge and understand the value of a philosophical 
doctrine- which is one of the Philosophy treasures of humanity, the "tool" theory, the philosophy of "semiofficial American lifestyle".

Currently in Vietnam, Pragmatism is a topic that attracts many people to research and introduce. However, because the Western philosophies besides Marxism (including pragmatism) in Vietnam are taught with limitation, they do not attract the appropriate attention from the researchers. So far, it can be stated that there is no work to study and introduce about the formation, development, and impacts of this doctrine in the U.S. and other countries comprehensively. The research works only briefly introduce the ideas of these philosophers; and evaluation still has much controversy. Therefore, the thorough research on this doctrine and its specific impacts in Vietnam has a significant meaning. This article introduces the way pragmatism came to Vietnam and its history in Vietnam.

\section{References}

[1] William James. Pragmatism A New Name for Some Old Ways of Thinking. eBook online at http://www.gutenberg.org/files/5116/5116-h/5116-h.htm

[2] James Campbell. One Hundred Years of Pragmatism Transactions of the Charles S. Peirce Society, Indiana University Press Vol. 43, No. 1, 2007, pp. 1-15.

[3] Đảng cộng sản Việt Nam. 2011. Tài liệu Đại hội XI. Nhà xuất bản Chính trị Quốc gia, Hà Nội. pp 67.

[4] Sơn, N. 2004. Lịch sử khẩn hoang Miền Nam. Nhà xuất bản: Trẻ, pp 75.

[5] Trần, T. G. 2012. Chính sách nô dịch về văn hóa của thực dân Pháp và một số trào lưu văn hóa trước năm 1945 ở Việt Nam, Trường Đại học Văn hoá Hà Nội, Nghiên cứu văn hoá - số 2 .

[6] Nguyễn, H. V. 2001. Giảng dạy triết học ở Việt Nam-nhìn lại chặng đường ba mươi năm phát triển, đổi mới. Kỷ yếu hội thảo 55 năm nghiên cứu và giảng dạy triết học. pp 678 .
[7] Christopher Torchia. 2009. Iraq War's Price Tag Nears Vietnam's. The Associated Press.

[8] Đoàn, T. 1959. Một vài nguyện vọng của người đọc tạp chí, Bách Khoa số 70 , ngày $1 / 12$.

[9] Trần, T. Đ. Đ. 1993. Văn Nghệ Nam Việt Nam 1954-1975. Nhà XB Văn Hoá, Thông Tin. pp 427.

[10] Trần, V, Đ. 2004. Đại Học Oxford, Anh Quốc. Hội Nghị Quốc Tê về Hiện Tượng Học 07.2004.

[11] Lavergne và Sassani. 1954. Phúc trình về hệ thống giáo dục ở VN. Education in VietNam. Washington D.C: U.S. Department of Health, Education \& Welfare.

[12] Nguyễn, T. L. 2006. Giáo dục ở miền Nam tự do trước 1975 (Education in South Vietnam before 1975). California: Lê Văn Duyệt Foundation, pp19

[13] Việt Nam Cộng Hòa , Hội đồng Văn hóa giáo dục 1972.

[14] Lê, X. K. 2011. Đại Học Miền Nam trước 1975: Hồi Tưởng và Nhận Định. Trích sách: Đại học Humboldt 200 năm (1810-2010): Kinh nghiệm thế giới và Việt Nam, Nhà xuất bản Tri thức.

[15] Nguyễn, T. L. 2006. Giáo dục ở miền Nam tự do trước 1975 (Education in South Vietnam before 1975). California: Lê Văn Duyệt Foundation. pp. 21.

[16] Nguyễn, M. L. 1988. Mấy trào lưu triết học phương Tây, nhà xuất bản Đại học và giáo dục chuyên nghiệp, pp351.

[17] Mary Hershberger, 1998. Traveling to Vietnam. Syracuse University Press.

[18] 30-4 và vị thế Việt Nam - Bài 3: Những người Mỹ thầm lặng http://phapluattp.vn/20100502105549921p0c1013/304-vavi-the-viet-nam-bai-3-nhung-nguoi-my-tham-lang.htm

[19] Trần, T. Đ. Đ. 2000. Văn Hóa, Văn Nghệ Nam Việt Nam 1954-1975, nxb Văn Hóa Thông Tin, Hà Nội, pp 779.

[20] Chỉ thị số 222-CT/TW, ngày 17-6-1975 của Ban Bí thư khoá III về công tác giáo dục đại học và chuyên nghiệp ở miền Nam trong thời gian trước mắt.

[21] Nguyên, N. 2005. Nghĩ dọc đường, NXB Văn nghệ, pp 155. 